\title{
A ROSA DE HIROXIMA
}

Pensem nas crianças

Mudas telepáticas

Pensem nas meninas

Cegas inexatas

Pensem nas mulheres

Rotas alteradas

Pensem nas feridas

Como rosas cálidas

Mas oh não se esqueçam

Da rosa da rosa

Da rosa de Hiroxima

A rosa hereditária

A rosa radioativa

Estúpida e inválida

A rosa com cirrose

A anti-rosa atômica

Sem cor sem perfume

Sem rosa sem nada.

\section{Vinícius de Moraes}

Disponível em:

MORAES, V. Nova antologia poética. São Paulo: Companhia das Letras, 2005. 